\title{
The Influence of Employees' Job Satisfaction Factors on Organizational Commitment
}

\author{
Anis Eliyana, \\ Airlangga University \\ Ria Mardiana Yusuf \\ Hasauddin University \\ Koko Prabowo \\ PT. Jaya Readymix Concrete
}

\begin{abstract}
This research aims to examine about organizational commitment in relation to the job satisfaction factors. Research is conducted on the production employees of PT Jaya Readymix Concrete (JYC) which amounted to 47 people. Data is collected from the questionnaire that was given directly to the respondent. Analysis techniques used in research is regression analysis between factors of employees' job satisfaction as independent variables, which consists of the ability utilization, compensation, relationship with co-workers, working conditions, recognition and achievement with organizational commitment as dependent variables. Based on the results of the regression analysis of linear regression model equations, we derived a formulation as follows: $Y=-1.012+0.184 X_{1}+0.581 X_{2}+0.080 X_{3}+0.118 X_{4}+0.136 X_{5}+0.165 X_{6}+e$. Results show that the job satisfaction factors simultaneously have a significant effect on organizational commitment in JYC with the coefficient of determination $\left(R^{2}\right)$ is 0.967, and that compensation is the dominant variables influencing employee's organizational commitment in the production department at JYC.
\end{abstract}

Keywords: Job Satisfaction, Organizational Commitment.

Introduction

Commitment as one of the most popular work attitudes has gain practitioner's attention and researchers [1,2]. For example, research has found that the greater the individual commitment to the organization, the greater their efforts in completing their work [3]. Organizational commitment includes a sense of job involvement, loyalty, and trust in the organization's values. To that end, the organization has an important role in increasing individual commitment, namely to ensure the individual is motivated and satisfied with their work [4].

Organizational commitment is an important indicator to measure the degree and extent to which an employee is in favor of organizational goals [5]. In addition, job satisfaction is also a reflection of the feelings of employees towards their work. This is evident in employees' positive attitude to the work that they have and the work 


\section{Anis Eliyana \\ Ria Mardiana Yusuf \\ Koko Prabowo}

environment. Conversely, an unsatisfied employee would exhibit a negative attitude toward their work in one form or another [6,7].

PT. Jaya Readymix Concrete (JYC), which located in Surabaya, Indonesia is one of the major companies in Indonesia that are engaged in the ready mix concrete. Production has expanded to various regions in Indonesia, and associated with largescale projects. Production activities of the company depends on the production staff who have the ability and expertise in running the production process, but there are still some constraints on the part of this production. Heavy workload and demands strict production targets, effect on employee turnover rate is quite high. It is therefore an arising needs to further investigated whether the production employees who have a high workload also has obtained a high level of job satisfaction due to low job satisfaction that have resulted in high employee turnover rate in the past. Employee turnover in JYC could be seen in Table 1 below:

Table 1. Employee Turnover Rate (2005 - 2010)

\begin{tabular}{|c|c|c|c|}
\hline Year & $\begin{array}{c}\text { Number of Employee } \\
\text { that Leave the } \\
\text { Organization }\end{array}$ & $\begin{array}{c}\text { Total Number of } \\
\text { Employee }\end{array}$ & Turnover \\
\hline 2005 & 16 & 82 & $19.51 \%$ \\
\hline 2006 & 19 & 91 & $20.88 \%$ \\
\hline 2007 & 15 & 93 & $16.13 \%$ \\
\hline 2008 & 17 & 105 & $16.19 \%$ \\
\hline 2009 & 14 & 111 & $12.61 \%$ \\
\hline 2010 & 12 & 115 & $10.43 \%$ \\
\hline & & Rata-Rata & $15.96 \%$ \\
\hline
\end{tabular}

Source: PT. Jaya Readymix Beton, Surabaya, Indonesia, 2012

Table 1 explicitly shown that the average turnover of employees from 2005 to 2010 is quite high (15.96\%). Highest turnover is occurred in 2006 amounting to $20.88 \%$. Even though from year to year turnover rate continues to decline, especially in 2010 which has the lowest employee turnover rate of $10.43 \%$ the value is still remains quite high. This indicates that there are problems related to employee satisfaction in their work and its impact on organizational commitment of employees in the JYC, especially in the production department.

\section{Literature Review}

The theory underlying the relationship between job satisfactions with organizational commitment is expectancy theory proposed by Victor $\mathrm{H}$. Vroom [8], which states, "The power that motivates a person to work hard in his job depends on the mutual relationship between what people want and need from the results of that employment." How much a person believes the company will provide gratification as a reward for their effort. When confidence is expected to be large enough to give them satisfaction, then someone would work hard and committed to the company or organization, and vice versa.

There are three aspects of commitment: (1) affective organizational commitment, (2) continuance organizational commitment, and (3) normative organizational commitment [9]. Of the three approaches, we could view commitment as a psychological condition that characterizes the relationship between employees and 
organizations and has implications for the individual's decision to stay or leave the organization. However, the nature of the psychological conditions for each form of commitment is very different. Employees with strong affective commitment remain in the organization because they want to; employees with a strong ongoing commitment would remain in the organization because they need to, while employees who have a strong normative commitment remain in the organization because they ought to [10].

Previous study [1 1] concluded that job satisfaction has a positive relationship with the employee's commitment to the company. Some experts also mentioned the relationship between job satisfaction with the commitment of employees [12], they suggest that job satisfaction as a component of organizational commitment that brought a sense of comfort to someone, which arise from the compatibility of their self-values with their work. Therefore, it could be inferred that if employees feel satisfied with what he earned from a job or a workplace, they tends to show high commitment to the company where he/she works. Furthermore, employees who have a high commitment will have a strong desire to keep working on the organization [13]. Individuals would fully involve themselves in their work as an act of contributing to the achievement of organizational goals.

Research on the influential factors of job satisfaction on organizational commitment that has been reviewed in this section concludes that both intrinsic job satisfaction and extrinsic job satisfaction generally have a significant relationship with the employee's commitment to the company [11]. Based on these studies, the following is the conceptual framework of this study as set out in Figure 1.

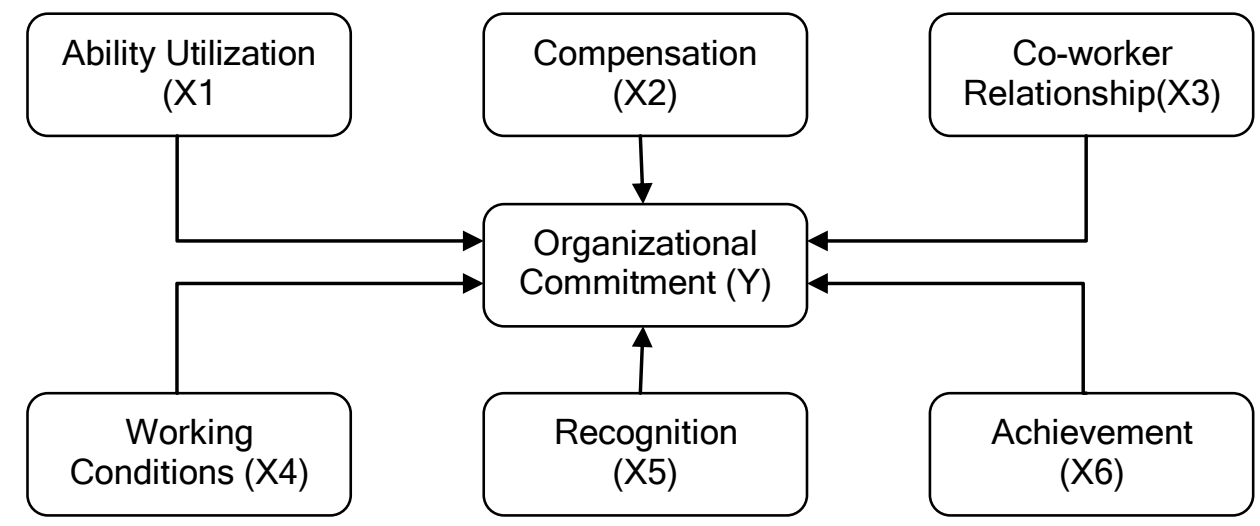

Figure 1. Conceptual Framework

Conceptual framework shown in Figure 1 illustrates the pattern of influence between the variables of job satisfaction and employee commitment to organizational variables. The hypotheses presented in this study are:

1. The factors of job satisfaction that consists of ability utilization, compensation, co-workers relationships, working conditions, recognition and achievement simultaneously have a significant effect on the organizational commitment of employees in the production department at JYC.

2. The dominant job satisfaction factors on organizational commitment in the production department at JYC are compensation.

\section{Research Methodology}




\section{Anis Eliyana \\ Ria Mardiana Yusuf \\ Koko Prabowo}

The population in this study was employees in the production department at JYC. Sampling technique used was non-probability sampling method with a saturation sampling technique. In this study, samples were taken from the entire population of employees in the production department at JYC for a total of 47 employees. This study uses the measurement indicators from the research instruments developed by The Minnesota Satisfaction Questionnaire (MSQ) introduced by Weiss, Dawis, England, \& Lofquist (1967). MSQ is used to measure job satisfaction factors and an organizational commitment as dependent variable that includes affective commitment, continuance commitment and normative commitment [10] based on the hypothesis that there is a relationship between these two variables, namely job satisfaction and organizational commitment.

\section{Results}

Analytical techniques used in the study were multiple linear regressions. The dependent variable is consist of organizational commitment (Y), and the independent variables $\left(X_{n}\right)$, namely the ability utilization $\left(X_{1}\right)$, compensation $\left(X_{2}\right)$, coworkers relationships $\left(X_{3}\right)$, working conditions $\left(X_{4}\right)$, recognition $\left(X_{5}\right)$, and achievement (X6). The results of regression analysis are shown in Table 2 below:

Table 2. Results of the regression analysis

\begin{tabular}{|l|c|c|c|c|}
\hline \multicolumn{1}{|c|}{ Variable } & $\begin{array}{c}\text { Regression } \\
\text { Coefficient( } \\
\text { B) }\end{array}$ & Std. Error & $\begin{array}{c}\text { Standardized } \\
\text { Beta }\end{array}$ & Sig. \\
\hline Ability Utilization $\left(X_{1}\right)$ & 0.184 & 0.074 & 0.167 & 0.017 \\
\hline Compensation $\left(X_{2}\right)$ & 0.581 & 0.077 & 0.461 & 0.000 \\
\hline $\begin{array}{l}\text { Co-workers relationships } \\
\left(X_{3}\right)\end{array}$ & 0.080 & 0.020 & 0.131 & 0.000 \\
\hline Working Condition $\left(X_{4}\right)$ & 0.118 & 0.050 & 0.118 & 0.022 \\
\hline Recognition $\left(X_{5}\right)$ & 0.136 & 0.066 & 0.122 & 0.046 \\
\hline Achievement $\left(X_{6}\right)$ & 0.165 & 0.062 & 0.152 & 0.011 \\
\hline $\begin{array}{l}\text { Constant }=-1.012 \\
\text { R Square }=0.967 \\
\text { R Sig }=0.000\end{array}$ & \\
\hline
\end{tabular}

Source: SPSS

Based on the results obtained from the regression analysis model, we obtained the multiple linear regression equation as follows:

$$
Y=-1.012+0.184 X_{1}+0.581 X_{2}+0.080 X_{3}+0.118 X_{4}+0.136 X_{5}+0.165 X_{6}+e
$$

The results of regression analysis with the above equation shows that the contribution of the independent variables $\left(X_{n}\right)$ on the dependent variable is organizational commitment $(Y)$, as indicated by the magnitude of the coefficient of multiple determination $\left(R^{2}\right)$ are 0.967 . This means that $96.7 \%$ level of organizational commitment is determined by changes in all the independent variables under study, thus the remaining $3.3 \%$ level of organizational commitment is determined by other variables not examined in the regression model.

Multiple correlation coefficient or multiple regression (R) based on the results of the analysis is $\mathbf{0 . 9 8 3}$. This coefficient indicates the level of relationship (correlation) 
between the independent variables $\left(X_{n}\right)$ with the dependent variable $(Y)$. R-value is close to the value 1.00 and shows a strong correlation between all independent variables with the dependent variable.

\section{First hypothesis testing}

The first hypothesis states that job satisfaction factors that are ability utilization, compensation, co-workers relationships, working conditions, recognition and achievement simultaneously have a significant effect on the organizational commitment of employees in the production department at JYC. This hypothesis was proven correct because the value of significance (Sig) that is 0.000 is smaller than the significance level of 0.05 .

\section{Second hypothesis testing}

The second hypothesis states that the most dominant factors influencing job satisfaction on organizational commitment of the production staff at JYC is compensation. To test this hypothesis, we could compare the standardized beta values of each variables of job satisfaction. When one of the variables of job satisfaction has the highest standardized beta value, then the variable have the most dominant influence on organizational commitment based on the t-test. Table 2 shown that the standardized beta value for each variable is significant as they all below 0.05 , apart from its positive value. The second hypothesis could be accepted as compensation (X2) has the highest standardized beta value than other job satisfaction factors.

\section{Discussion}

The results showed that job satisfaction factors significantly influence the organizational commitment. Thus, we could imply that these factors have affected onto each other and with each other in the daily working environment at JYC. Employee commitment will be stronger if all of the job satisfaction factors that are expected by employees could be satisfied by the company. Although compensation is regarded as the most dominant factors that influence organizational commitment and in accordance with previous studies [14], but other factors cannot be ignored, as they will mutually support one another.

Compensation as the most important factor in increasing organizational commitment also needs to be supported by career advancement or achievement. Even though employees are satisfied with the compensation that they received, but if they cannot improve their career at the company, over time this would have an effect on the employee's commitment to the company, as employee could not develop his ability and work skills. Furthermore, co-workers should be able to work well together as even though compensation is high, but the employee does not have a good relationship with their co-worker, the employee will tend to not feel comfortable in the working atmosphere like that, and in the long run would decrease their sense of commitment to the enterprise.

\section{Conclusion}




\section{Anis Eliyana \\ Ria Mardiana Yusuf \\ Koko Prabowo}

With compensation being the dominant factor influencing organizational commitment, companies should really put an effort to give a proper assessment on the ability, experience, and the magnitude of the responsibility of the employee. The company should have a complete record of the employee's job description, as a consideration in determining the appropriate compensation. Furthermore, duties and responsibilities of each employee need to be specified clearly, so that the company could provide fair compensation in accordance with the magnitude of the burden of responsibility hold by each employee.

In order to enhance employees' general ability, manager should give more opportunities for employees to solve work problems with the full support of the company. This is important as employees could develop their ability better within the company, would build a loyalty to the company, since they has gained good experience within the company.

Employee's job satisfaction in relation with their career advancement within the company also needs to be maintained and to be improved better to make employees feel proud to have a career in the company. Things to note in regard with this are the opportunity of the employee to demonstrate their potential within the company. Active involvement needs to be supported by the company so that employee could explore their potential skills better.

In order their relation with co-workers, companies need to pay attention on the opinions given by employees about their job problems. Every employee should be given the opportunity to express their opinions so that they feel valued by a company [15]. Companies need to provide guidelines for better working rules of cooperation among employees so that every employee can work well with their colleagues.

With regard to improve employees' recognition better, manager must pay attention to the employee's work progress [16]. This attention would make employees feel valued as their work is recognized as part of an effort to achieve organizational goals. Attention from managers would increasingly improve employee closeness to their manager so that a sense of responsibility and commitment to the company would be higher.

Finally, to improve the satisfaction on working conditions, the company could provide a comfortable working atmospheres, especially regarding security and safety issues because of the employee's job is quite risky [17]. The company's attention to this condition would make employee have a higher commitment to company because the company pays great attention to the employee.

\section{References}

[1] D.Riley. Turnover Intentions: The Mediation Effects of Job Satisfaction, Affective Commitment and Continuance Commitment. Master Thesis. University of Waikato, New Zealand (2006)

[2] R.B.Dunham, J.A.Grube and M.B.Castaneda. Organzational Commitment: The Utility of An Integrative Definition. Journal of Applied Psychology, 79 (1994) 


\section{Jurnal Manajemen Teori dan Terapan Tahun 5. No. 2. Agustus 2012}

[3] L.W.Porter and R.M.Steers. Motivation and Work Behavior. 12Th Edition. New York: McGraw-Hill (2003)

[4] M.G.Aamodt. Applied Industrial/Organizational Psychology. California: Wadsworth Publishing Company. (1991)

[5] S.P.Robbins. Perilaku Organisasi. Edisi Bahasa Indonesia. Jakarta: PT. Prenhallindo (2003)

[6] T.H.Handoko. Manajemen Personalia dan Sumber Daya Manusia. Yogyakarta: BPFE-UGM (2007)

[7] R.L.Daft and R.A.Noe. Organizational Behavior, International Edition. USA: SouthWestern Publishing (2001)

[8] M.Hasibuan. Organisasi dan Motivasi. Jakarta: Penerbit Bumi Aksara (1999)

[9] J.P.Meyer and N.J.Allen. A Three Component Conceptualization of Organizational Commitment. Human Resource Management Review, 1 (1990)

[10] N.J.Allen and J.P.Meyer. The Measurement and Antecedents of Affective, Continuance and Normative Commitment to The Organization. Journal of Occupational Psychology, 63 (1991)

[11] E.Gunlu, M.Aksarayli, and N.S.Percin. Job Satisfaction and Organizational Commitment of Hotel Managers in Turkey. International Journal of Contemporary Hospitality Management. Vol. 22(5) (2009)

[12]Yuwono. Psikologi Industri dan Organisasi. Surabaya: Fakultas Psikologi Universitas Airlangga (2005)

[13] A.Umiker, Interrelationship of work commitment constructs. Work and Occupation, 18 (1999)

[14] A. Anis, I.Rehman, A.Nasir and N.Safwan. Employee Retention to Training and Development: A Compensation Perspective. African Journal of Business Management. Vol. 4(7) (2003)

[15] F.Luthans. Organizational Behavior. Ninth Edition. New York: McGraw-Hill Company (2001)

[16] J.W.Walker. Human Resource Strategy. New York: McGraw-Hill Inc (2002)

[17] W.B.Werther and K.Davis. Human Resource and Personnel Management. 5Th Edition. Boston: McGraw-Hill (1996) 